\title{
Distribusi tertangkapnya ikan selar pada lembaran jaring soma darape di rumpon
}

\author{
Distribution of caught trevally on a net sheet of darape gill net operated in FADs
}

ONAN FALEN DIMARA*, JOHNNY BUdIMAN dan CORNELIS F.T. MANDEY

Program Studi Pemanfaatan Sumberdaya Perikanan, Fakultas Perikanan dan Ilmu Kelautan, Universitas Sam Ratulangi, Manado 95115

\begin{abstract}
Trevally (Selaroides sp) is one of the potential small pelagic fishery resources in the waters of Indonesian teritory. This resource is distributed in eight fishing areas, namely the Straits of Malacca, Java Sea and the Sunda Strait, the Indian Ocean, the Makassar Strait, the Pacific Ocean, the Gulf of Tomini, Banda Sea, and the Arafura Sea (National Commission on Marine Fish Stock Assessment Resources, 1998). Trevally is an important export commodity since 1993. One of useful fish behavior in the development and improvement of fishing method using "soma darape", a surface gill net, is the distribution of caught fish on the net operated at FADs. With this knowledge, at least some constraints in determining technical design and operation of fishing gear can be overcome. Soma darape in Kelurahan Malalayang Satu Timur, Manado operated around FADs by way of blocking fish out of soma pajeko (purse seine). Soma darape operated by 1-2 fishermen.
\end{abstract}

Keywords: round scad, gill net, purse seine, FADs

\begin{abstract}
ABSTRAK
Ikan selar (Selaroides sp) merupakan salah satu sumberdaya perikanan pelagis kecil yang potensial di perairan toritorial Indonesia. Sumberdaya tersebut tersebar pada delapan daerah penangkapan, yaitu Selat Malaka, Laut Jawa dan Selat Sunda, Samudera Hindia, Selat Makasar, Laut Pasifik, Teluk Tomini, Laut Banda, dan Laut Arafura (Komisi Nasional Pengkajian Stok Sumberdaya Ikan Laut, 1998). Ikan selar adalah komoditi ekspor yang penting sejak tahun 1993. Salah satu tingkah laku ikan yang bermanfaat dalam pengembangan dan perbaikan metode penangkapan dengan jaring insang "soma darape" adalah tingkat distribusi tertangkapnya ikan pada alat tangkap soma darape di rumpon. Dengan pengetahuan ini, setidaknya berbagai kendala dalam penentuan desain dan teknis operasi alat tangkap dapat diatasi. Soma darape atau jaring insang permukaan yang ada di Kelurahan Malalayang Satu Timur, Kota Manado dioperasikan di sekitar rumpon dengan cara menghadang ikan yang keluar dari soma pajeko (pukat cincin). Dalam operasi penangkapan soma darape dilakukan oleh 1-2 orang nelayan.
\end{abstract}

Kata-kata kunci: ikan selar, jaring insang, pukat cincin, rumpon

\section{PENDAHULUAN}

Usaha perikanan pelagis di perairan Teluk Manado sudah lama dilakukan dengan mengunakan peralatan yang relatif sederhana dan tradisonal. Salah satu alat tangkap sebagai penunjang usaha perikanan masyarakat nelayan di Malalayang Satu Timur yaitu jaring insang permukaan atau yang disebut masyarakat soma darape rumpon dengan hasil tangkapan ikan tude atau selar (Selaroides $\mathrm{sp).}$

\footnotetext{
*Penulis untuk penyuratan; email: onan.dimara@yahoo.com
}

Ikan selar merupakan salah satu sumberdaya perikanan pelagis kecil yang potensial di perairan teritorial Indonesia. Sumberdaya tersebut tersebar pada delapan daerah penangkapan, yaitu Selat Malaka, Laut Jawa dan Selat Sunda, Samudera Hindia, Selat Makasar, Laut Pasifik, Teluk Tomini, Laut Banda, dan Laut Arafura (Komisi Nasional Pengkajian Stok Sumberdaya Ikan Laut, 1998). Ikan selar/ikan malalugis putih adalah komoditi ekspor yang penting sejak tahun 1993. (Katiandagho dkk., 2000). 
Jenis-jenis alat tangkap yang digunakan untuk menangkap selar biru di perairan timur Indonesia adalah small purse seine, pukat pantai, jaring insang hanyut, dan pancing. Penggunaan alat-alat tangkap tersebut tidak lepas dari pengetahuan tentang tingkah laku ikan. Salah satu tingkah laku ikan yang bermanfaat dalam pengembangan dan perbaikan metode penangkapan dengan jaring insang soma darape adalah tingkat distribusi tertangkapnya ikan pada alat tangkap jaring insang soma darape di rumpon. Dengan pengetahuan ini, setidaknya berbagai kendala dalam penentuan desain dan teknis operasi alat tangkap dapat diatasi.

Jaring insang soma darape yang ada di Sulawesi Utara umumnya dioperasikan di tepi pantai dengan kedalaman perairan 2-4 meter. Soma darape juga merupakan jaring insang yang memanfaatkan tingkah laku ikan yang beruaya mengikut pasang surut. Berbeda dengan soma darape yang ada di Kelurahan Malalayang Satu Timur Kecamatan Malalayang Kota Manado. Soma darape di lokasi tersebut dioperasikan di sekitar rumpon dengan cara menghadang ikan yang keluar dari soma pajeko (purse seine) sehingga masyarakat nelayan Malalayang Satu menyebutnya soma darape rumpon. Dalam operasi penangkapan jaring insang soma darape rumpon dilakukan oleh 1-2 orang nelayan.

Pendekatan yang dapat dilakukan adalah dengan memahami perilaku ikan sebagai bagian dari komponen biologis. Dari berbagai perilaku ikan yang dapat dikaji sebagai bahan pertimbangan dalam pengelolaan sumberdaya, salah satunya adalah distribusi tertangkapnya ikan pada alat tangkap jaring insang soma darape rumpon. Nelayan jaring insang soma darape rumpon memanfaatkan ikan-ikan yang lolos dari pukat cincin, di mana nelayan mengoperasikan jaring insang soma darape tersebut pada jarak 1-2 meter di belakang jaring pukat cincin.

\section{METODE PENILITIAN}

Penelitian dilakukan di Teluk Manado Kelurahan Malalayang Satu Timur, Kota Manado. Metode yang diterapkan dalam melakukan penelitian ini adalah metode deskriptif. Metode deskriptif adalah suatu metode dalam meneliti suatu metode yang tujuannya untuk memberikan gambaran secara sistematis, faktual dan akurat tentang fakta untuk mendapatkan makna serta implikasi dari masalah yang diselidiki. Dalam hal ini pengunaan 4 buah jaring insang soma darape dalam operasi penangkapan ikan, dengan mempunyai ukuran yang sama, yakni panjang $25 \mathrm{~m}$, lebar $3 \mathrm{~m}$, hangin ratio $60 \%$ dan besar mata jaring $13 / 4$ inchi $(44,45 \mathrm{~mm})$.

Jaring dioperasikan secara bersamaan, jaring diikatkan pada tali ris atas jaring pukat cincin. Alat tangkap ini dioperasikan di belakang jaring pukat cincin dengan mengunakan perahu tipe pelang dengan tenaga pendorong motor katinting 5 PK merek Honda

\section{HASIL DAN PEMBAHASAN}

Hasil tangkapan yang diperoleh dari empat buah jaring insang soma darape di rumpon dalam 5 trip pengoperasian seluruhnya adalah ikan tude dengan jumlah keseluruhan 2531 ekor. Adapun hasil tangkapan ke empat buah jaring ditampilkan pada Tabel 1.

Pada jaring insang soma darape rumpon 1 (Tabel 1) terlihat bahwa hasil tangkapan pada mata 1-10 jumlah hasil tangkapan sebanyak 526 ekor diikuti oleh jumlah hasil tangkapan pada distribusi mata 11-20 dengan jumlah hasil tangkapan sebanyak 123 ekor dan 18 ekor pada mata 21-3. Pada jaring 2, hasil tangkapan menunjukkan distribusi mata 1-10 jumlah hasil tangkapan sebanyak 483 ekor diikuti oleh jumlah hasil tangkapan pada distribusi mata 11-20 dengan jumlah hasil tangkapan sebannyak 146 ekor dan 7 ekor pada distribusi mata 21-31. Pada jaring 3, hasil tangkapan menunjukkan distribusi mata 1-10 jumlah hasil tangkapan sebanyak 522 ekor diikuti oleh jumlah hasil tangkapan pada distribusi mata 11-20 dengan jumlah hasil tangkapan sebanyak 28 ekor dan 2 ekor pada distribusi mata 21-31. Sedangkan pada jaring 4, distribusi hasil tangkapan pada lembaran jaring mata 1-10 menunjukkan jumlah hasil tangkapan sebanyak 632 ekor diikuti oleh jumlah hasil tangkapan pada distribusi mata 11-20 dengan jumlah hasil tangkapan sebannyak 44 ekor. Untuk keseluruhan distribusi hasil tangkapan pada berbagai mata jaring dapat dilihat pada Gbr. 1. 
Tabel 1. Ditrisbusi jumlah hasil tangkapan pada lembaran jaring

\begin{tabular}{ccrrrrrr}
\hline Jaring & $\begin{array}{c}\text { Mata jaring } \\
\text { ke }\end{array}$ & \multicolumn{5}{c}{ Trip } & \multicolumn{2}{c}{ Total } \\
\cline { 2 - 7 } 1 & $1-10$ & 70 & 125 & 20 & 161 & 150 & 526 \\
& $11-20$ & 30 & 15 & 15 & 63 & & 123 \\
& $21-30$ & 4 & 14 & & & & 18 \\
\hline & Total & 104 & 154 & 35 & 224 & 150 & 667 \\
\hline 2 & $1-10$ & 96 & 200 & 53 & 90 & 44 & 483 \\
& $11-20$ & 10 & 102 & 34 & & & 146 \\
& $21-30$ & 7 & - & - & - & - & 7 \\
\hline \multirow{3}{*}{3} & Total & 113 & 302 & 87 & 90 & 44 & 636 \\
\hline & $1-10$ & 142 & 50 & 94 & 200 & 36 & 522 \\
& $11-20$ & 11 & 17 & & & & 28 \\
& $21-30$ & 2 & & & & & 2 \\
\hline \multirow{2}{*}{4} & Total & 155 & 67 & 94 & 200 & 36 & 552 \\
\hline & $1-10$ & 251 & 74 & 87 & 164 & 56 & 632 \\
& $11-20$ & 3 & 36 & 5 & & & 44 \\
& $21-30$ & & & & & & \\
\hline & Total & 254 & 110 & 92 & 164 & 56 & 676 \\
\hline
\end{tabular}

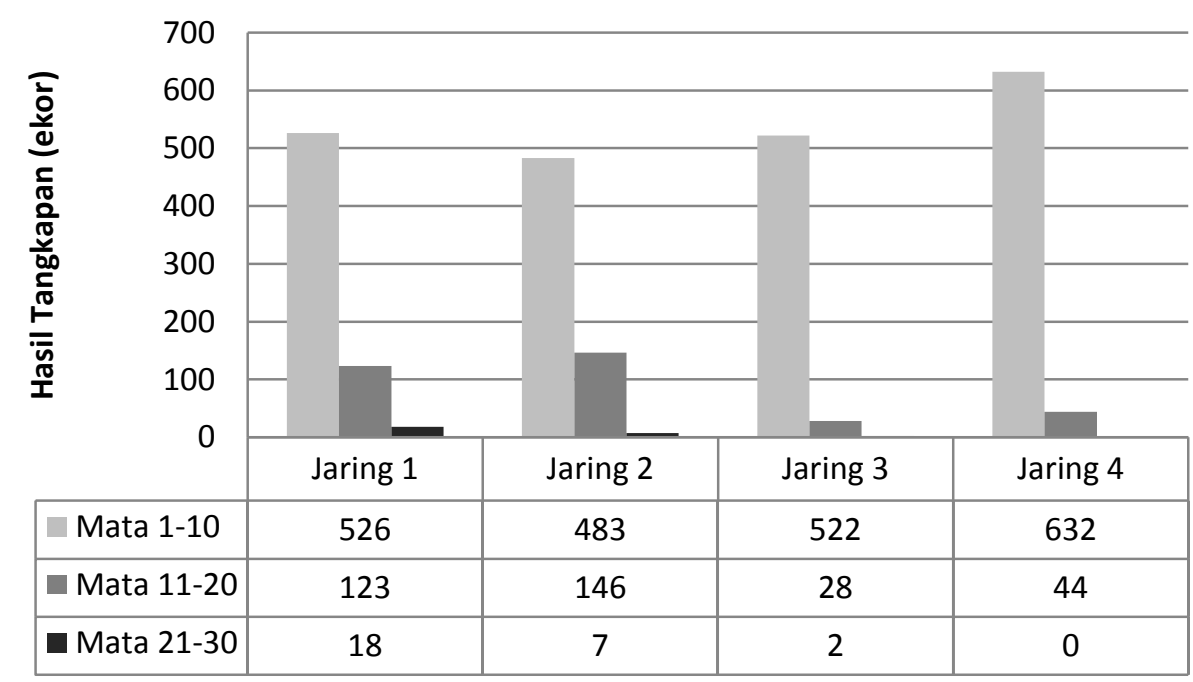

Gambar 1. Distribusi hasil tangkapan ikan tude pada berbagai mata jaring

Dari keseluruhan distribusi hasil tangkapan menunjukkan mata 1-10 jumlah hasil tangkapan yang lebih banyak yaitu 2163 ekor dan lembaran jaring mata ke 11-20 sebanyak 341 ekor dan pada mata ke 21-30 sebanyak 27 ekor. Distribusi hasil tangkapan yang dominan pada lembaran jaring mata ke 1-10 menunjukkan bahwa setelah meloloskan diri dari pukat cincin ikan selar tidak langsung berenang ke arah dalam tapi terdistribusi sekitar permukaan perairan pada kedalaman 0-50 $\mathrm{cm}$ dari permukaan perairan. Dominan ikan-ikan yang tertangkap pada lembaran jaring mata 1-10. Dalam proses penangkapan dengan jaring insang soma darape rumpon nelayan juga melakukan penangkapan dengan sibu-sibu (serok) di mana ikan setelah meloloskan diri tidak langsung melarikan diri ke arah dalam perairan tetapi berenang beberapa saat di sekitar permukaan 
perairan. Ikan-ikan dalam jangkauan sibu-sibu dengan mudah dapat ditangkap dan ikan-ikan yang lain terjerat di lembaran jaring insang soma darape rumpon. Hal inilah membuat ikan-ikan dominan tertangkap pada lembaran jaring mata ke 1-10 diikuti oleh mata ke 11-20 dan sedikit tertangkap pada mata ke 21-30 dan tidak ada ikan yang tertangkap pada lembaran ke 31 ke arah dalam lembaran jaring.

Untuk komposisi ukuran hasil tangkapan ikan selar dengan jaring isang soma darape rumpon pada berbagai trip operasi penangkapan dapat dilihat pada Gbr. 2.

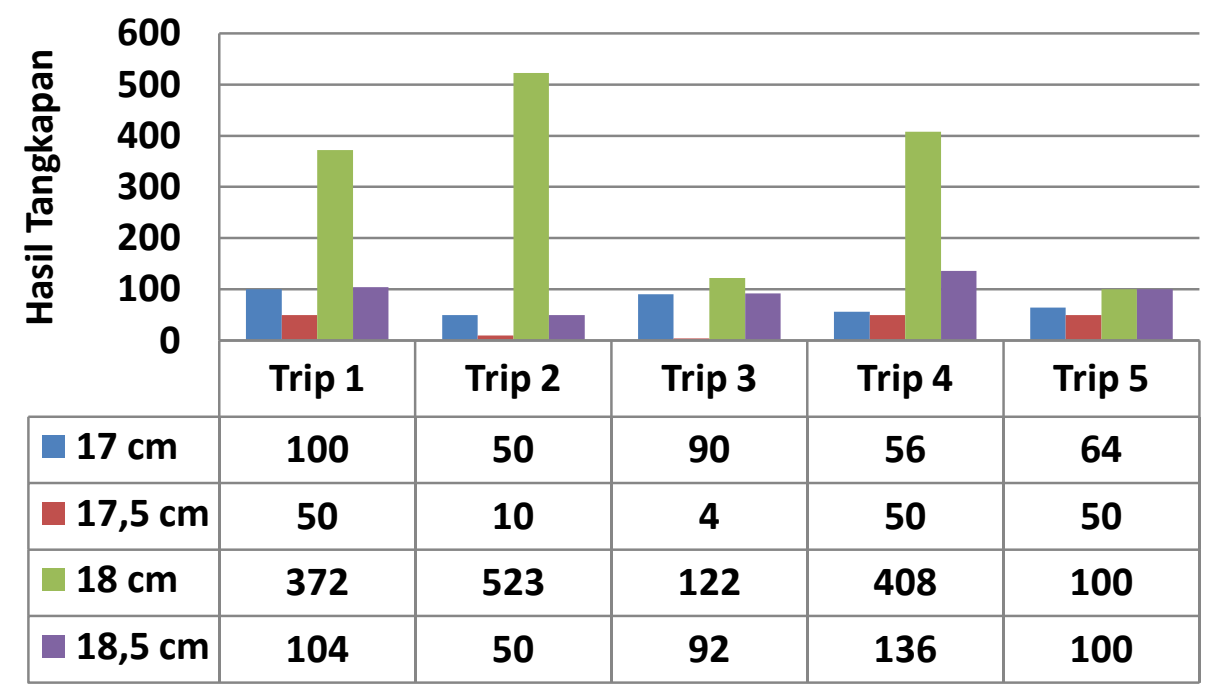

Gambar 2. Distribusi ukuran ikan hasil tangkapan pada berbagai trip operasi penangkapan.

Dari Gbr. 2 terlihat bahwa pada trip 1 ukuran ikan $18 \mathrm{~cm}$ mendominasi hasil tangkapan yaitu sebanyak 372 ekor diikuti oleh ukuran ikan 18,5 cm (104 ekor), 17 cm (100 ekor) dan ukuran ikan $17 \mathrm{~cm}$ sebanyak 50 ekor.

Trip 2 ukuran ikan $18 \mathrm{~cm}$ didominasi hasil tangkapan yaitu sebanyak 523 ekor sedangkan ukuran ikan $17 \mathrm{~cm}$ dan $18,5 \mathrm{~cm}$ mempunyai jumlah tangkapan yang sama yaitu sebanyank 50 ekor sedangkan ukuran ikan $17,5 \mathrm{~cm}$ sebanyak 10 ekor. Trip 3 ukuran 18, cm mendominasi hasil tangkapan yaitu sebanyank 122 ekor diikuti oleh ukuran ikan 18,5 cm sebanyak 92 ekor dan ukuran ikan $17, \mathrm{~cm}$ sebanyak 90 ekor sedangkan ukuran ikan 17,5 cm sebanyak 4 ekor. Trip 4 ukuran ikan 18 , cm mendominasi hasil tangkapan sebanyak 408 ekor diikuti oleh ikan ukuran $18,5 \mathrm{~cm}$ sebanyak 136 ekor dan ukuran ikan $17 \mathrm{~cm}$ sebanyak 56 ekor, ukuran 17,5 , cm berjumlah 50 ekor. Trip 5 ukuran ikan 18,0 cm dan ukuran 18,5 cm sama-sama mendominasi hasil tangkapan yang sama yaitu 100 ekor.
Dalam sistimatika biologi perikanan ikan selar pertama kali matang gonad pada ukuran panjang $13,5 \mathrm{~cm}$ untuk betina dan $16,5 \mathrm{~cm}$ untuk jantan. Ikan ini umumnya mempunyai ukuran panjang total bervariasi antara $11,0-27,0 \mathrm{~cm}$ dengan panjang maksimum 47,0 cm (Fishbase 2013). Sehingga hasil tangkapan secara keseluruhan pada ukuran 17,0-18,5 cm merupakan ikan dewasa yang bisa ditangkap.

Jaring insang soma darape rumpon ini memanfaatkan ikan-ikan yang lolos dari proses penarikan pukat cincin. Dalam proses meloloskan diri dari pukat cincin ikan selar melompat selama proses penarikan jaring. Proses melompatnya ikan ini makin banyak pada saat lingkaran jaring soma pajeko makin kecil. Lolosnya ikan selar ini bukan dari proses lolosnya ikan dari mata jaring soma pajeko yang merupakan ikan-ikan kecil akan tetapi ikan-ikan dewasa yang layak menjadi target penangkapan jaring insang soma darape di rumpon. Hal ini dibuktikan dengan ukuran ikan yang tertangkap minimum sebesar $17,0 \mathrm{~cm}$. 


\section{KESIMPULAN}

Ikan selar umumnya tertangkap pada lembaran jaring mata ke 1-20 atau pada kedalaman jaring 0$50 \mathrm{~cm}$ dari permukaan perairan. Panjang total ikan tude yang tertangkap berukuran $17,0-18,5 \mathrm{~cm}$ dengan hasil tangkapan yang dominan pada ukuran $18,0-18,5 \mathrm{~cm}$.

\section{DAFTAR PUSTAKA}

Arusmoto, dkk. 1999. Komisi Nasional Pengkajian Stok Sumber Ikan laut 1998.
Fishbase. 2013. 32500 Species, 299700 Common Names, 52500 Pictures, 48700 References, 2010 Collaborators, 700000 Visits/Month. Sumber: http://www.fishbase.org, diakses tanggal 9 April 2013.

Katiandagho, E.M., C.F.T. Mandey, E. Reppie, H.J. Kumajas., M.S. Sompie, F. Silooy. 1991. Metode Penagkapan Ikan. Fakultas Perikanan. Universitas Sam Ratulangi, Manado. 